\title{
Comparative Growth Performance of Camel Calves Feeding on Natural Range Land and Supplementary Diet
}

\author{
Sallam A Bakheit1, I Adam Idris', Ali A Hassabo² and Ebrahiem \\ $\mathrm{MA}^{1 *}$ \\ ${ }^{1}$ Departement of Animal Production, University of Kordofan, Sudan \\ ${ }^{2}$ Admenstration of West Kordofan University, The chancellor of West Kordofan \\ University, Sudan
}

\section{Research Article \\ Volume 4 Issue 1}

Received Date: February 11, 2019

Published Date: March 21, 2019

DOI: $10.23880 /$ oajvsr-16000173

*Corresponding author: MA Ebrahiem, Departement of Animal Production, Faculty of natural resources and Environmental Studies, University of Kordofan, Sudan, Email: mahaali5656@gmail.com

\section{Abstract}

The study aimed to investigate the impact of supplementary feeding on the young camels calve growth rate and daily gain. A total of 16 heads of young male camel calves from the Arabic camel breeds were selected and divided into four equal groups $(1,2,3,4)$. Four heads of camel calves in each group, their body weight ranged from 176-220 kg. Experimental animal in group one was control supplemented nothings just depend on the natural range land, group two was feed on watermelon seeds, group three was allowanced concentrated diet composed of ground nut cake and the animals in group four intake mixture diet consist of watermelon seeds and ground nut cake $50 \%$ for each. The body weight of the experimental animal was determined biweekly using table balance. The random complete experimental design was used and the Analysis of variance and Tukey test were applied for data analysis and means separation. The results indicated that the average Body weights of the camel calves were $174.75 \pm 3.3,275.93 \pm 9.0,241.50 \pm 8.5$ and $236.50 \pm 8.2 \mathrm{Kg}$, in group one, two, three and four respectively. The higher body weight was recorded in group two $(275.93 \pm 9 \mathrm{Kg})$ in which the animals feed on watermelon seeds and followed by group three and four $(241.50 \pm 8.5$ and $236.50 \pm 8.2$ ) respectively. On the other hand the less camel calves body weight was obtained in group one (control) that experimental animals not intake supplementary feeding. Highly differences ( $\mathrm{P} \leq 0.01)$ were obtained in the body weight between the groups. The daily gain of the first group, second, third and fourth were $214 \pm 12 \mathrm{~g}, 624 \pm 28 \mathrm{~g}, 542 \pm 19 \mathrm{~g}$ and $528 \pm 12 \mathrm{~g}$, respectively, while no significant differences $(\mathrm{P} \geq 0.01)$ between diets groundnut cake $242 \mathrm{~kg}$ and mixture diet $237 \mathrm{~kg}$. The protein content was higher in ground nut cake $41 \%$ when compared to the protein content in watermelon seeds $36 \%$, on the other hand the percentage of fat was highest in watermelon seeds $27.8 \%$ compared to ground nut cake $13.4 \%$.

Keywords: Supplementary Feeding, Camel Calves; Growth Rate; Daily Gain 


\section{Introduction}

Sudan has over 130 million heads of livestock and ranked a second country in the world in camel population. There are 3.908 million heads of camels in Sudan according to last estimation [1].

Camels in the Sudan are spread in a belt known as camel belt. Camels Migration to the southern parts of the country is limited by diseases such as Trypanosomosis, internal and external parasites and the unsuitability of the clay soils with camel pads [2]. Camels dependent mainly on natural vegetation for feed, camel growth rates and productivity in general is reflected by availability and quality of feed available each year. After weaning camel calf growth rates are in turn affected by feed availability and their nutritional value. To develop sustainable feeding systems of camel production there is a need envisage alternative feeding pattern. Studying the effects of supplementation of weaned camel calves may give an option for a new feeding strategy though it is a practice that is rarely followed by the traditional herders [3]. This study aimed to investigate the impact of supplementary feeding on the young camel calves' growth rate and daily gain and to determine the nutritive value of feed ingredients.

\section{Materials and Methods}

\section{Study Area}

El-Obeid town is the capital of North Kordofan State. North Kordofan lies between latitudes $11^{\circ}: 15$ / and $16^{\circ}: 30 /$ $\mathrm{N}$ and longitudes $27^{\circ}$ and $32^{\circ} \mathrm{E}$ at an altitude of 560 meters above sea level. Maximum temperatures range between 30 and $35^{\circ} \mathrm{C}$, with peaks of above $40^{\circ} \mathrm{C}$ during the months of April, May and June prior to the rainy season. The rainy season extends from July to October with the greatest monthly rainfall in August. Average annual rainfall is about $280 \mathrm{~mm}$. Minimum temperatures varies between $18-22^{\circ} \mathrm{C}$ during the winter season, which extends from November to February [4]. The crops grown in the area are millet, sorghum and maize for food together with groundnuts and sesame for food and cash, watermelon and Roselle for cash. Crop residues are fed to animals raised by the farmers or sold to animal breeders in the area. Oil seed cakes are used for intensive animal production patterns that are being adopted by some investors around the town [5].

\section{Experimental Animals Identification}

Total of Sixteen (16) male camel calves (locally GAUAD) from the Sudanese Arabi breed, experimental animals were selected divided into four equal groups $(1,2,3,4)$ four heads of camel calves in each group, their body weight ranged from $176-220 \mathrm{~kg}$. The camels-calves were maintained under semi-intensive management system. Each of the experimental animals was ear-tagged to facilitated identification. Camel calves in group one (A) were left on natural pasture as control. The other three groups of animals were feed natural pasture supplemented either watermelon seeds in second group two (B), the third group (C) ground nut cake and group four (D) on a ration composed of mixture of watermelon seeds and ground nut cake in equal percentage, (Table 1). All animals were kept during night in closed pen and set free during the midday. The natural pasture that was offered to camel calves consisted of Aristida ssp. (BAIAD or GAO). On the other hand two $\mathrm{kg}$ of the concentrated diets was offered daily to each animal. Water was provided daily. The experimental animals were treated against internal and external parasites by spraying weekly against ticks and the all experimental animals were drenched by Ivermectin against internal parasite and worms. At the midday all the camel calves were brought to grazing areas where they select could select from available browse for one hour. The experimental animals were supplemented with $200 \mathrm{~g}$ common salt as brine biweekly.

\section{Data Collections}

The experimental camel calves weighed at the beginning of the experiment and every two weeks thereafter using a traditional balance. The live body weight of camel calves were obtained through direct weighing using a static weighing scale balances for birth weight and table balances. For camel calves handling, restraining proved to be highly efficient without causing any stress on the animals while affording maximum security for the workers. This was done by strong ropes made of cloths.

\section{Statistical Analysis}

The data were subjected to statistical analysis programme using 8 Version 2.0 [6] Software computer Package described by Analysis of Variance (ANOVA) according to Senedecor and Cochran, and Gomez and Gomez $[7,8]$. Turkey test was used for means separation.

\section{Results and Discussion}

The Changes in live body weight of camel calves in the four treatments were plotted in Table 3 \& Figure 1, showed that the average body weights of the camel calves were $174.75 \pm 3.3,275.93 \pm 9.0,241.50 \pm 8.5$ and 


\section{Open Access Journal of Veterinary Science \& Research}

$236.50 \pm 8.2 \mathrm{Kg}$, in treatments $1,2,3$ and 4 respectively, on the other hand the less camel calves body weight was obtained in the (control treatment). The results showed that there were highly differences $(\mathrm{P}<0.01)$ in the body weight between the treatments. The higher body weight was recorded in treatment $2(275.93 \pm 9 \mathrm{Kg})$ in which the animals feed on watermelon seeds. Followed by

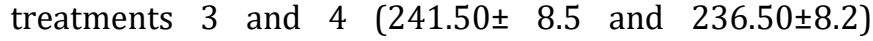
respectively. The less camel calves body weight was obtained in treatment 1 (control) that experimental animals not intake supplementary feeding. There were highly differences $(\mathrm{P} \leq 0.01)$ in the body weight gain between the treatments. The daily body weight gain of treatments $1,2,3$ and 4 were $214 \pm 12 \mathrm{~g}, 624 \pm 28 \mathrm{~g}, 542 \pm 19 \mathrm{~g}$ and $528 \pm 12 \mathrm{~g}$ respectively. While no significant differences $(P \geq 0.01)$ between diets (groundnut cake 242 $\mathrm{kg}$ and mixture diet $237 \mathrm{~kg}$ ) were detected. The protein content was higher in ground nut cake $41 \%$ which compared to the protein content in watermelon seeds $36 \%$ on and the percentage of fat was highest in watermelon seeds $27.8 \%$ compared to ground nut cake $13.4 \%$. The highest body weight was recorded in the treatment of water melon seed this may be attributed to enrich of the diet by the protein and energy. The results of the present study were in line of the findings of Nagpal and Manju [9] who postulated that body weights of camel calves are varying between $241-276 \mathrm{Kg}$. Also these findings were in agreement with the results of Turki, et al. [10] who study the body weight of Sudanese camel calves and recorded that the average body weight of camel calves of tow years old were $175.75 \pm 0.25 \mathrm{~kg}$. On the other hand the results of the present study were less than the findings of Iqbal, et al. [11] who studied the growth performance of camel calves kept under station and farmers' conditions. Also the result of this study showed that there is no significant different between treatment 3 and 4 which the animal allowanced diet consist of groundnut cake and water melon seeds respectively. These results may be referred to the desirability of the diet and the level of the feed intake. This findings were disagreement with the findings of Bakheit [3] who revealed that the live body weight of the camel calves showed highly significant $(\mathrm{P}<0.01)$ different, the body weight of the calves under semi-intensive system during six, 12 and 18 months of age were $123.42 \pm 2.21,221.04 \pm 2.17$ and $326.26 \pm 2.40$ kg respectively, on the other hand the body weight of the camel calves under traditional system during six months, 12 and months are $96.42 \pm 1.59,159.70 \pm 2.35$ and 208.62 $\pm 2.50 \mathrm{~kg}$, respectively. This disagreement may be attributed to the different of management system and the different of the type of supplementary feeding.

\begin{tabular}{|c|c|c|c|c|}
\hline & I & II & III & IV \\
\hline Natural grazing & 100 & & & \\
\hline Groundnut cake & - & + & -- & + \\
\hline Watermelon seeds & - & - & + & + \\
\hline
\end{tabular}

Table 1: Percent ingredients in rations fed to the experimental.

\begin{tabular}{|c|c|c|c|c|c|c|c|}
\hline FEED & DM & OM & CP & CF & CF & EE & Ash \\
\hline $\begin{array}{c}\text { Watermelon } \\
\text { Seeds }\end{array}$ & 94.54 & 97.77 & 36 & 18 & 18 & 27.75 & 2.23 \\
\hline $\begin{array}{c}\text { Groundnut } \\
\text { Cake }\end{array}$ & 94.53 & 93.38 & 41 & 10 & 10 & 13.35 & 6.62 \\
\hline
\end{tabular}

Table 2: The Chemical composition and nutritive value of supplementary feeding.

\begin{tabular}{|c|c|}
\hline Sources of Feed & Average Weight (kg) \\
\hline Control & $174.75 \pm 3.3 \mathrm{a}$ \\
\hline Water melon seeds & $275.93 \pm 9.8 \mathrm{~b}$ \\
\hline Ground nut seed cake & $241.50 \pm 8,5 \mathrm{c}$ \\
\hline $\begin{array}{c}\text { Water melon seeds } \\
\text { +Ground nut seed cake }\end{array}$ & $236.50 \pm 8.2 \mathrm{c}$ \\
\hline
\end{tabular}

Table 3: The Weight of Calves at different sources of feed. *values in the column share in same superscript show no significant difference.

\begin{tabular}{|c|c|}
\hline Sources of feed & Daily gain (gram) \\
\hline Control & $214 \pm 12 \mathrm{c}$ \\
\hline Water Melon Seeds & $624 \pm 28 \mathrm{a}$ \\
\hline Groundnut Seed Cake & $542 \pm 19 \mathrm{~b}$ \\
\hline $\begin{array}{c}\text { Water Melon Seeds } \\
\text { +Groundnut seed cake }\end{array}$ & $528 \pm 17 \mathrm{~b}$ \\
\hline
\end{tabular}

Table 4: The daily gain Camel calves at different sources of feed.

*values in the column share in same superscript show no significant difference.

\section{Conclusion}

The higher body weight gain was recorded when the animals feed on watermelon seeds and followed by animals fed on groundnut seed cake alone. The mixture diet of the groundnut cake and water melon seeds was scoured the third place in body weight gain to camel calves. The less camel calves body weight gain was obtained when experimental animals not intake supplementary feeding and depended totally on natural grazing. There is no significant difference $(\mathrm{P} \geq 0.01)$ between diets groundnut cake and mixture diet. The protein content was higher in groundnut cake when compared to protein content in watermelon seeds. The 


\section{Open Access Journal of Veterinary Science \& Research}

percentage of fat was highest in watermelon seeds compared to groundnut cake.

\section{References}

1. MARF-Ministry of Animal Resource and Fisheries (2005) Department of statictics, annual reports, Khartoum, Sudan. Station and farmers condition. Proceeding of the international Statistic and Information, Khartoum, Yearly report, Sudan, pp: 1215.

2. Bakheit SA, Majid AMA, Nikhala AMMA (2006) Camels (Camelus dromedarius) under pastoral systems in North Kordofan, Sudan: seasonal and parity effects on milk composition. Journal of Camelid Science 1: 3236.

3. Bakheit SA (2008) Comparative growth performance of Camel calves kept under composition in North Kordofan State. Proceeding of the $1^{\text {st }}$ Conference of the international Society of Camelids Research and Development (ISO CARD) Sudan, pp: 15-17.

4. Technoserve H (1987) Credit Component Base line Survey and U.S under semi- intensive and traditional system in western Sudan. Technoserve Inc., Agricultural.

5. Ebrahiem MA, Galallyn HA, Bashir AY (2015) Skin \Leather Quality of Some Sudan Goats under
Range Condition. Global Journal of Animal Scientific Research 3(2): 337-341.

6. STATISTIX 8 (2007) Statistix 8 user's manual. Version 2.0-USAD (United States department of Agriculture).

7. Snedecor GW, Cochran WE (1967) Statistical Methods. Sixth edition. The Lowa State, University of Lowa, USA.

8. Gomez KA, Gomez AA (1984) Statistical procedure for the agriculture research. $2^{\text {nd }}(\mathrm{edn})$ Wily and Sone. Inc.

9. Nagpal AK, Manju GP (2005) Nutrient utilization of gram strow (Cicer arietinum) based Complete feed blocks in camel nutrition. The Indian J of Anim Sci 75(1): 146-154.

10. Turki S, Harzallah AS, Sammari C (2007) Occurrence of harmful dinoflagellates in two different Tunisian ecosystems: the lake of Bizerte and the gulf of Gabe`s. Cah Biol 47: 253-259.

11. Iqbal A, Gill RA, Khan BB, Younan M, Jasra AW (2000) Comparative growth performance of camel calves kept under station and farmer's conditions. India Journal of animal sciences 53(2): 198-200.

12. Bank of Sudan and US Agency for Agricultural Development, Elobied, Sudan, pp: 204. 